\title{
Online Shop Customers' Behaviour: E-Service Quality, Attitude and Actual Use
}

\author{
Amalia Hasta Insani \\ Department of Accounting \\ Universitas Airlangga \\ Surabaya, Indonesia \\ hastainsani@gmail.com
}

\author{
Noorlailie Soewarno \\ Department of Accounting \\ Universitas Airlangga \\ Surabaya, Indonesia \\ noorlailie@gmail.com \\ Isnalita \\ Department of Accounting \\ Universitas Airlangga \\ Surabaya, Indonesia \\ isnalita@feb.unair.ac.id
}

\begin{abstract}
Online Shop has become inseparable in the life of consumer behaviour of Indonesia, in using application of Shopee, Lazada, Tokopedia, Bukalapak and Jd.id. This is known to increase the real consumption growth of Indonesian society. The purpose of this study is to determine the effect of e-service quality on the determinants of attitudes and actual users on online shop users' behaviour in Indonesia. This study uses the Partial Least Square or Warp PLS 6.0 method to test the hypothesis using 206 respondents from online shop users in Indonesia. The results showed that service quality (ESQ) and consumer behaviour (ATT) were found to have a positive effect on actual users (USE). While the quality of service (ESQ) was found to have no positive effect on actual usage (USE) in using the online web shop, these findings provide insight into consumer behaviour, e-commerce, marketing and technology. This study contributes to the growing literature on customer attitudes in online shop-based purchases.
\end{abstract}

Keywords-e-service quality; attitude; actual use; behaviour

\section{INTRODUCTION}

In today's technologically sophisticated era, people's lifestyles are given easy access to various information in the fields of economy, commerce and even shopping. Today's public shopping styles adapt advanced technology that can be accessed through smartphones anywhere. Comfort and convenience are what cause online shopping in Indonesia to grow rapidly. Online shopping is a means of buying and selling by ordering through a website or social media with payment via transfer or directly. In Indonesia, there are rapidly growing websites that sell online because there is no tax collection on the sale. According to [1], not all people like this style of shopping like that; research data from Nielsein states that 60 percent of Indonesia's population is sometimes still more satisfied to buy goods directly from the store for more satisfaction in choosing the desired product based on expectation. It also depends on the consumer's perspective on how the services are delivered.
Attitude and e-service quality is important for the continuation of the online shop. Online shops always try to give good e-service quality and satisfactory service. According to [2], E-service quality is key to the long-term benefits of the digital age; e-service quality is critical to the attractiveness and loyalty of customers to the service industry in Indonesia. Good e-service quality will result in satisfaction and influence in high usage levels.

Based on data from media discussion held in West Merdeka forum, monitored by Ministry of Kominfo Central Jakarta on Saturday 12 August 2017, Head of BPS Bapak Suhariyanto stated that people's purchasing power is still strong, which can be proven from the contribution of household to gross domestic product (GDP) still being dominant. Components of household consumption expenditure grew significantly in the second quarter of 2017, i.e. 4.95 percent when compared to 4.94 percent in the first quarter. The Head of BPS does not deny that there has been a shift in capital due to public spending from conventional to nonconventional transactions or online. According to Faisal Basri (Economic observer from UI), in the last 5 years, the real growth of public consumption reached an average increase of 5 percent. This proves the people of Indonesia contribute greatly to economic growth.

According to an article written by [1] internet users in Indonesia reached 82 million people, although Indonesia left behind other countries in regards to technology; this helped with increasing smartphone users, development of the internet, the usage of debit and credit cards and the increasing level of consumer confidence in e-service quality of online shops. Research focusing on online web shops in various countries, shows: purchasing of air tickets via the web in Taiwan [3]; use of e-banking in Taiwan [4]; E-business experience in Greece [5]; online purchase via the internet at the University in the United States [6]; as well as e-services on sports web in Australia[7]. 
This study uses the adoption model of [8]-[10] to determine the e-service quality and customer attitude towards the actual use of online shops in Indonesia. Research on the quality of electronic services and customer attitudes contributes to the growing literature on customer attitudes in online shop-based purchases. Subjects in this study are students and communities in Indonesia who often shop at online shops in Indonesia. This is because they can judge how e-service quality can affect their attitude and actual use when shopping online.

\section{LITERATURE REVIEW}

\section{A. E-Service and Actual Use}

According to [3], E-service quality is the extent to which websites can facilitate efficient, effective shopping, purchasing and delivery of products and services. In a study conducted by [11], the attributes of e-service quality significantly affect the intent of use. This research advances the literature on the relationship between e-service quality and customer satisfaction and between customer satisfaction and actual online shop use.

In the context of this research, e-service quality services give customers easy access to actual use, such as online web shops that can provide all customer needs, maintain customer transaction data security, always resolves errors on the system quickly and is complete with features that can make customers' use of the web become more routine and repetitive. Therefore, this study hypothesised that:

\section{H1: E-service quality positively affects the high actual use} of an online shop.

\section{B. Factor of E-Service Quality}

E-service quality is a long-term assessment of the quality of an organisation. E-service is a web-based service that connects the internet with the interaction between customers and sellers through the web. According to [6], e-service quality makes it easy to spend money and time effectively for a purchase and receive effective delivery. According to [8, 9], There was seven items of dimensions called E-SERVQUAL were developed, i.e. including efficiency, system availability, fulfilment, privacy, responsiveness, compensation and contact. However, this study only uses four items of dimension namely system availability, fulfilment, privacy and responsiveness [8], [9], [12] It is because the researchers look at previous researchers using such four items [8], [9], [13].

According to [9], responsiveness is the precise timing given by the online e-service shop service providers to customers who transact business online. Responsiveness has been shown to have a significant positive relationship and affect actual usage [12], [14]. In this study, if the response provided by the online shop service makes the customer feel satisfied, then it can affect the customer's attitude with repeated use. According to [15], privacy is a measure of the extent to which the website is secure and protects all customer privacy information so that no information can be shared with other online websites. [16], [17] found that privacy has all that is found to predict customer attitudes toward online web shops. According to [9], privacy is a guarantee of transaction data confidentiality such as credit card information, debit cards and protecting individual information. In this research, the information can be recognised and explored through the internet, which is a privacy issue that must be handled, because disclosing customer's privacy information for commercial purposes should not happen; this is a determinant of customer trust to online web shops. Privacy has been shown to have a significant positive relationship and affect actual usage [14], [18].

Reliability/fulfilment in e-service quality, refers to the technical function of a web, to measure whether it works properly or not [8], [9]. This is supported by the research of [16], [17], who found that reliability has all that is found to predict customer attitudes toward the online web shop. According to [12], system availability refers to the technical function of a system. [19] found that system availability and nine other e-service items significantly affect e-service services to online store websites. In this study, system availability is described as the availability of an online web shop system that provides online purchasing service for customers and provides a smooth process if you want to transact.

According to [20], the value comes from the ability of an object that has a significant influence on the individual. The study found that the quality of e-service affects consumer attitudes in using sports websites [21], as well as on information quality, and customer satisfaction [13], [22]. [18] found that three attributes of e-service quality, namely entertainment, informativeness and organization can be associated from the website against positive attitudes. [23] found that e-service services have an effect on consumer attitudes. When customers believe they receive good quality from the online shop, they will respond with good attitude. Therefore, this study proposes and tests the following hypotheses:

\section{H2: E-service quality positively affects the attitude of online shop customers.}

\section{Determinants of Attitude}

The attitude of an individual in using the system depends on the services provided by the online shop. Attitudes can be formed with trust and each customer needs to be considered before making a decision. A study by [24]-[26] stated that user attitudes positively affect the web use by user. [27]-[29] developed five attributes that are perceptions of innovation attitudes such as relative advantage, compatibility, triability, complexity and observability. However, this study only uses three attributes: relative advantage, compatibility and complexity [30], [31].

Relative advantage is the degree to which an innovation is perceived as better than the idea of replacing, and the extent to which an innovation is seen as superior to its predecessor [32]. [31]found that relative profits have a significant effect on customer attitudes toward online web shops. Compatibility is a measure of how flexible innovations with the beliefs, experiences, values and needs of the adopters. [30], [31]found that compatibility has a significant positive effect on the 
attitude of online shop trading at Hong Kong. In the context of this research, when the online web shop can meet customer needs and in accordance with the current lifestyle, customers will respond with a positive attitude because it feels comfortable while shopping.

Complexity is defined as an important component that affects the attitude towards the use of information systems or technology. Complexity is similar to that of TAM, the extent to which innovations are seen by potential adoptions because they are relatively difficult to use and difficult to understand. This is supported by [31] research, which states that complexity significantly affects customers' attitude. When the online web shop can innovate in various ways to look attractive, then the customer will show the attitude or interest and, thus, always getting the feeling to shop online. When the online web shop supports the need and provides trust, the customer will demonstrate a dependent attitude to actual use to meet their needs and wants. Therefore, this research proposes and tests the hypothesis as follows:

H3: Customer attitude positively affects the actual use of an online shop.

\section{RESEARCH METHOD}

This study surveys students and communities who often use the online shop to shop. The population used in the study included students and the public who shop at online shops in Indonesia. The sample of the study comprised of students and people who often shopped at online shops such as Shopee, Lazada, Tokopedia, Bukalapak and Jd.id. The data obtained from the questionnaire comprised of 214 responses. A total of 8 responses were eliminated due to the questionnaire being incorrectly filled out, so the final sample of the study was 206 responses.

This study uses questionnaires to examine the factor of eservice quality and attitude factors on actual usage. Proxy for e-service quality is reliability/fulfilment privacy and responsiveness. While proxy for attitude is relative advantage, compatibility and complexity.

Compatibility is the extent to which innovations are considered consistent with existing values, while complexity speaks to how innovation is considered relatively difficult to use. Relative advantage is the degree to which an innovation is perceived to be better than the idea that it replaces. Actual Usage is the percentage of use of a system by the user.

E-service quality survey items are adapted from [8], [9], [13]. Customer attitude survey items are adapted from [27, 28]. Items of actual use survey are adapted from [18]. Responses to questions in the research questionnaire were measured on a five-point Likert scale (interval scale), ranging from strongly disagreeing to strongly agreeing. This research model was tested using the Partial Least Square Structural Equation Model (PLS-SEM) and analysed using Warp PLS 6.0 .

\section{RESULTS AND DISCUSSION}

\section{A. Outer Model (Measurement) Model}

This model was used where the correlation between the latent variable and the indicator is tested by the validity test of convergent, discriminant validity test, and reliability test as according to [33]. Some items were removed from the data because the outlier values $(<0.70)$ are FUL1-5 for reliability / fulfilment, RES3-5 for responsiveness (RES), AVA1-3 for system availability (AVA), PR1-3 for privacy (PR), RA3-5 for relative advantage (RA), as well as CT1-4 for compatibility (CT) and COM1-4 for complexity (COM). The AVE value indicates the following: ESQ (0.800), ATT (0.814) and USE (0.759). For a reliability test, the requirements are composite reliability $(\mathrm{CR})>0.70$ and Cronbash's alpha $>0.60$. The reliability test results using CR showed ESQ (0.889), ATT (0.898) and USE (0.863). Then test results using Cronbach alpha showed that ESQ (0.750), ATT (0.772) and USE (0.683) and reliability test results are also achieved.

\section{B. Outer Model (Measurement) Model}

Figure 1 shows the findings of hypothesis testing. It revealed that $26 \%$ of the variation in electronic service quality is in the determinants of attitudes and actual use of online shops in Indonesia in the construction of ESQ, ATT, and USE. E-service quality (ESQ) proxied by RES positively affects RES $(\beta=0.29, p<0.01)$ in ATT. Conversely, the attitude determinants (ATT) proxied with RA also have a significant positive effect with RA $(\beta=0.48, p<0.01)$ on USE. Therefore, $\mathrm{H} 2$ and $\mathrm{H} 3$ are supported. Furthermore, only unsupported H1s such as the e-service quality (ESQ) have no effect on actual usage (USE) with $(\beta=0.07, p=0.26)$.

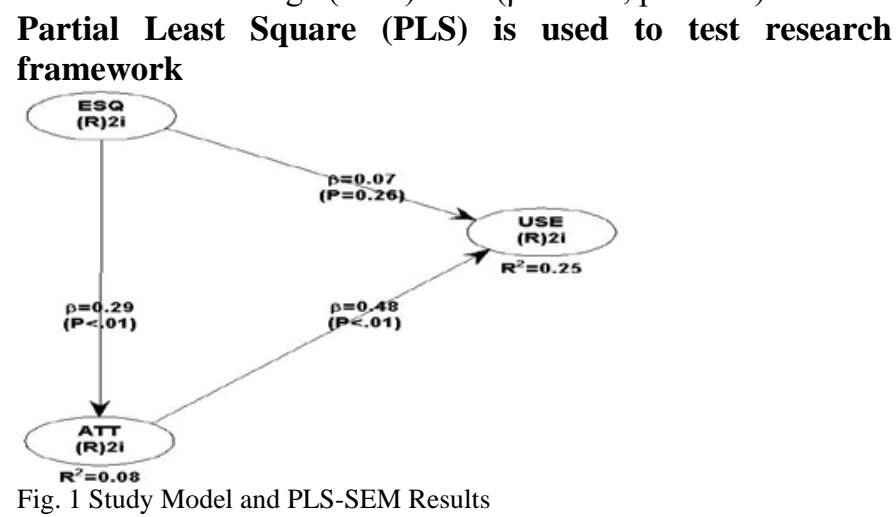

\section{Discussion}

E-Service Quality and Actual Use

The results in the picture reveal that e-service quality has no effect on actual high usage on the online web shop. This finding is supported by previous research [14]. This is because good e-service quality does not necessarily result in customers always wanting to use the web. Customers will definitely differentiate as it relates to online shops.

E-Service Quality and Attitude

The results in the picture reveal that e-service quality affects the customers' attitude to the online web shop. This proves that customers that experience good quality from 
online shop will respond with a positive attitude. [16], [34] show that e-service quality has a positive effect on consumer attitudes on the website. [23] found that e-service quality affects customer attitudes.

Attitude and Actual Use

The results in the picture reveal that e-service quality affects the actual use of the online web shop. This is supported by[30], [31], which expresses that user attitudes affect actual usage. Research from [24]-[26], [29], [35] stated that user attitudes have a positive effect on website usage by the user. If the web user feels the online web shop is in accordance with the way he/she shops online and finds it easier to collect information from the web, then the attitude shown by the user is able to prove that quality of service can meet all kinds of user needs.

\section{CONCLUSION AND LIMITATIONS}

This study was conducted to determine the effect of eservice quality on the determinants of attitudes and actual users on the behaviour of online shop users in Indonesia. For E-service quality in this study, there are only two indicators that have a significant effect, namely Responsiveness and Relative Advantage. The results show that Responsiveness is a significant indicator for measuring the quality of electronic services, whereas relative advantage is a significant indicator for measuring customer attitudes. However, e-service quality does not affect customer attitudes due to a lack of customer understanding of the online shop.

Limitations in this study assess the direct impact of attitudes and e-service quality of online store website services without testing the intention of users to use the online web shop, as the questionnaire on demographic data is less specific. Both Respondents' objects in this research should be narrowed, because they are more dominated respondents who have not worked and are aged between 15-20 years. Researchers can then add to the variable intent of the user and the behavioural intention on two online web shops. In the questionnaire, we forgot to add a question regarding budget to distinguish the range of budget that is often used for shopping online.

\section{REFERENCES}

[1] R. Mahatma, "Data Statistik Mengenai Pertumbuhan Pangsa Pasar ECommerce di Indonesia Saat ini [Statistical data about Recent Indonesian E-commerce Market Share]," ed., 2016. [Online]. Available at: buattokoonline.id.

[2] P. Oliveira, A. V. Roth, and W. Gilland, "Achieving competitive capabilities in e-services," Technol. Forecast. and Soc. Change, vol. 69, pp. 721-739, 2002/09/01/ 2002.

[3] S.-F. Luo and T.-Z. Lee, "The influence of trust and usefulness on customer perceptions of e-service quality," Soc. Behav. and Personality: an Int. J., vol. 39, pp. 825-837, 2011.

[4] H. C. T. Bruce and L. Wen-Chuan, "Measuring the service quality of internet banking: scale development and validation," European Bus. Rev., vol. 22, pp. 5-24, 2010.

[5] S. Emmanouil and G. C. K., "E-service quality: comparing the perceptions of providers and customers," Managing Service Quality: An Int. J., vol. 19, pp. 410-430, 2009.
[6] G. J. Udo, K. K. Bagchi, and P. J. Kirs, "An assessment of customers' e-service quality perception, satisfaction and intention," Int. J. of Inform. Manage., vol. 30, pp. 481-492, 2010/12/01/ 2010.

[7] C. Jamie and O. C. Aron, "Exploring the relationships between e-service quality, satisfaction, attitudes and behaviours in content-driven e-service web sites," J. of Serv. Marketing, vol. 24, pp. 112-127, 2010.

[8] A. Parasuraman, V. A. Zeithaml, and A. Malhotra, "ES-QUAL: A multiple-item scale for assessing electronic service quality," J. of serv. res., vol. 7, pp. 213-233, 2005.

[9] V. A. Zeithaml, A. Parasuraman, and A. Malhotra, "Service quality delivery through web sites: a critical review of extant knowledge," J. of the academy of marketing sci., vol. 30, p. 362, 2002.

[10] C. Van Slyke, F. Belanger, and C. L. Comunale, "Factors influencing the adoption of web-based shopping: the impact of trust," ACM SIGMIS Database: the DATABASE for Advances in Inform. Syst., vol. 35, pp. 32-49, 2004.

[11] H. Khanifar, M. Nia, M. Javad, Z. Molavi, and M. Emami, "Factors influencing the intendancy of e-banking: An integration of TAM \& TPB with e-service quality," 2012.

[12] Y. C. Hu, J. H. Wang, and L. P. Hung, "Evaluating microblogging e-service quality using ANP," J. of Multi-Criteria Decision Analysis, vol. 19, pp. 89-111, 2012.

[13] A. Pearson, S. Tadisina, and C. Griffin, "The role of e-service quality and information quality in creating perceived value: antecedents to web site loyalty," Inform. Syst. Manage., vol. 29, pp. 201-215, 2012.

[14] A. C. k., O. A. Atinuke, A. O. J., and E. I. O., "E-banking users' behaviour: e-service quality, attitude, and customer satisfaction," Int. J. of Bank Marketing, vol. 34, pp. 347-367, 2016.

[15] E. T. H. and M. A. A., "Customer participation in online co-creation experience: the role of e-service quality," J. of Res. in Interactive Marketing, vol. 9, pp. 313-336, 2015.

[16] M. Wolfinbarger and M. Gilly, ". comQ: dimensionalizing, measuring, and predicting quality of the e-tail experience," 2002.

[17] M. T. Elliott and P. S. Speck, "Factors that affect attitude toward a retail web site," J. of Marketing Theory and Practice, vol. 13, pp. 40-51, 2005.

[18] L.-d. Chen, M. L. Gillenson, and D. L. Sherrell, "Enticing online consumers: an extended technology acceptance perspective," Inform. \& Manage., vol. 39, pp. 705-719, 2002/09/01/ 2002.

[19] M. Kim, J.-H. Kim, and S. J. Lennon, "Online service attributes available on apparel retail web sites: an ES-QUAL approach," Managing Service Quality: An Int. J., vol. 16, pp. 51-77, 2006.

[20] I. Ajzen, Attitudes, personality, and behavior: McGraw-Hill Education (UK), 2005.

[21] J. Carlson and A. O'Cass, "Exploring the relationships between eservice quality, satisfaction, attitudes and behaviours in content-driven e-service web sites," Journal of services marketing, vol. 24, pp. 112127, 2010.

[22] P.-Y. Chu, G.-Y. Lee, and Y. Chao, "Service Quality, Customer Satisfaction, Customer Trust, and Loyalty in an E-Banking Context," Soc. Behav. and Personality: an int. j., vol. 40, pp. 1271-1283, // 2012.

[23] A. O'Cass and D. Grace, "Exploring consumer experiences with a service brand," J. of Product \& Brand Management, vol. 13, pp. 257268, 2004.

[24] I. Akinyemi, E. Asani, and A. Adigun, "An investigation of users' acceptance and satisfaction of e-banking system as a panacea towards a cashless economy in Nigeria," J. of Emerging Trends in Computing and Inform. Sci., vol. 4, pp. 954-963, 2013.

[25] N. Oly Ndubisi and Q. Sinti, "Consumer attitudes, system's characteristics and internet banking adoption in Malaysia," Manag. Res. News, vol. 29, pp. 16-27, 2006.

[26] N. Jahangir and N. Begum, "The role of perceived usefulness, perceived ease of use, security and privacy, and customer attitude to engender customer adaptation in the context of electronic banking," African J. of Bus. Manage., vol. 2, p. 32, 2008.

[27] E. M. Rogers and D. Williams, "Diffusion of," Innovations (Glencoe, IL: The Free Press, 1962), 1983.

[28] M. Rogers Everett, "Diffusion of innovations," New York, vol. 12, 1995. 
[29] H. Karjaluoto, M. Mattila, and T. Pento, "Electronic banking in Finland: consumer beliefs and reactions to a new delivery channel," J. of Financial Serv. Marketing, vol. 6, pp. 346-361, 2002.

[30] O. Folorunso, R. O. Vincent, A. F. Adekoya, and A. O. Ogunde, "Diffusion of innovation in social networking sites among university students," Int. J. of Comput. Sci. and Security, vol. 4, pp. 361-372, 2010.

[31] W. M. Olatokun and L. J. Igbinedion, "The adoption of automatic teller machines in Nigeria: An application of the theory of diffusion of innovation," Issues in Informing Sci. \& Inform. Technol., vol. 6, 2009.
[32] L. Carter and F. Bélanger, "The utilization of e-government services: citizen trust, innovation and acceptance factors," Inform. Syst. J., vol. 15, pp. 5-25, 2005.

[33] M. Sholihin and D. Ratmono, Analisis SEM-PLS dengan WarpPls 3.0.[Analysis SEM-PLS with WarpPls 3.0.]. Yogyakarta: Penerbit ANDI Yogyakarta, 2013.

[34] B. Yoo and N. Donthu, "Developing a scale to measure the perceived quality of an Internet shopping site (SITEQUAL)," Quarterly J. of Electron. commerce, vol. 2, pp. 31-45, 2001.

[35] A. A. Aderonke, "An empirical investigation of the level of users acceptance of e-banking in Nigeria," J. of Internet Banking and Commerce, vol. 15, p. 1, 2010. 